\title{
Mechanical transmission of lumpy skin disease virus by Aedes aegypti (Diptera: Culicidae)
}

\author{
C. M. CHIHOTA, L. F. RENNIE, R. P. KITCHING* AND P. S. MELLOR \\ Institute for Animal Health, Pirbright Laboratory, Ash Road, Pirbright, Woking GU24 ONF, UK
}

(Accepted 23 November 2000)

\section{SUMMARY}

Aedes aegypti female mosquitoes are capable of the mechanical transmission of lumpy skin disease virus (LSDV) from infected to susceptible cattle. Mosquitoes that had fed upon lesions of LSDV-infected cattle were able to transmit virus to susceptible cattle over a period of 2-6 days post-infective feeding. Virus was isolated from the recipient animals in 5 out of 7 cases. The clinical disease recorded in the animals exposed to infected mosquitoes was generally of a mild nature, with only one case being moderate. LSDV has long been suspected to be insect transmitted, but these findings are the first to demonstrate this unequivocally, and they suggest that mosquito species are competent vectors.

\section{INTRODUCTION}

Capripoxviruses cause economically significant diseases of sheep (sheep pox), goats (goat pox) and cattle (lumpy skin disease, LSD). The diseases are characterized by pyrexia, generalized or localized pock lesions and lymphadenopathy [1, 2]. LSD, an OIE list A disease, causes major production losses, especially in high-producing exotic breeds, and is a constraint on trade [3]. Sheep and goat pox are endemic throughout Asia and Africa while LSD is restricted to Africa, with only one confirmed report from outside this continent in Israel in 1989 [4, 5]. Epidemiological evidence indicates the involvement of biting insects in the transmission of lumpy skin disease virus (LSDV) $[6,7]$. The incidence of disease is highest during wet periods coinciding with periods of biting fly abundance and wanes with the onset of the dry season. In the 1959 Kenyan outbreak of LSD, there were reports of high infestation of Aedes natronius and Culex mirificus during some outbreaks [7]. Similarly, the 1989 Israeli outbreak of capripox is thought to have been the result of infected Stomoxys calcitrans being

\footnotetext{
* Author for correspondence.
}

carried on the wind from Ismailiya in Egypt $[4,5]$. Stomoxys calcitrans, has also been shown to mechanically transmit capripoxvirus between sheep in the laboratory [8-10]. Mechanical transmission of a number of poxviruses by biting arthropods is well documented, and includes myxoma virus where $A e$. aegypti has been identified as an important vector [11]. Mosquitoes have also been shown to mechanically transmit Shope fibroma virus and fowl pox virus $[12,13]$. The present study was undertaken to determine whether Ae. aegypti can act as an efficient mechanical vector of LSDV.

\section{MATERIALS AND METHODS}

\section{Virus isolate}

The LSDV isolate used in this study was supplied by Dr J. A. House (Plum Island Animal Disease Centre, USA) and was originally recovered from cattle in an outbreak in Ismailiya, Egypt in 1989. The virus was grown on lamb testis (LT) cell cultures and harvested when $90 \%$ of the cells showed cytopathic effect (CPE). The LT cultures were freeze-thawed three 
times, clarified by low speed centrifugation $(200 \mathrm{~g}$, $15 \mathrm{~min}$ ) and stored at $-20{ }^{\circ} \mathrm{C}$ until required.

\section{Cell cultures}

Primary LT tissue cultures were prepared from the testes of prepubertal lambs [14]. LT cells were grown in $175 \mathrm{~cm}^{2}$ plastic tissue culture flasks in $50 \mathrm{ml}$ of Glasgow Modified Eagle's Medium (GMEM) supplemented with $10 \%$ foetal calf serum and antibiotics. The flasks were kept at $37^{\circ} \mathrm{C}$ and $4 \% \mathrm{CO}_{2}$. Once a confluent monolayer was formed, the cells were split at a ratio of $1: 3$. The LT cells were used to a maximum of 10 passages, to ensure sensitivity to capripoxvirus.

\section{Virus isolation}

Blood samples collected in heparinized vacutainers were placed in plastic universal bottles and centrifuged at $600 \mathrm{~g}$ for $20 \mathrm{~min}$. The buffy coats were pippeted off and carefully placed in fresh universal bottles to which $20 \mathrm{ml}$ of cold GMEM had been added. The bottles were then centrifuged at $600 \mathrm{~g}$ for $20 \mathrm{~min}$ and the supernatants decanted. Red blood cell lysis was achieved by adding $10 \mathrm{ml}$ of cold double-distilled water followed by $10 \mathrm{ml}$ of cold $2 \times$ GMEM and the universal bottles were centrifuged at $600 \mathrm{~g}$ for $20 \mathrm{~min}$. This was repeated until clear pellets were obtained. The pellets were then resuspended and overlaid on LT cell cultures, which were observed for signs of CPE at 9 days. If no CPE was observed a second passage was carried out.

\section{Virus neutralization index}

Blood samples from experimental animals were collected in non-heparinized vacutainers on day 31 post mosquito feeding. The sera were separated, diluted 1:5 with GMEM and then heat inactivated at $56^{\circ} \mathrm{C}$ for $30 \mathrm{~min}$. Aliquots of $100 \mu \mathrm{l}$ of the diluted sera were placed in each well of 96-well microtitre plates. Serial tenfold dilutions of LSDV (Ismailiya) from neat to $10^{-8}$ were prepared in GMEM. To each well of the plates, $100 \mu \mathrm{l}$ aliquots of the virus dilutions were added using four replicates per dilution and, following incubation at $37^{\circ} \mathrm{C}$ for $1 \mathrm{~h}$, LT cells $(50 \mu 1)$ were added to each well at a concentration of $4 \times 10^{5}$ cells $/ \mathrm{ml}$. The wells were examined for evidence of CPE by light microscopy after 7 days and the end- points determined [15]. The virus neutralization index was taken as the difference between the titre in the presence of test serum and day 0 serum from the same animal. An index greater than or equal to 1.5 was considered positive [16].

\section{Infection of animals and mosquitoes}

Two steers (a Holstein-Friesian and an Angus cross Jersey) were inoculated at six sites each on the neck, flank and abdomen with $1 \mathrm{ml}$ of LSDV inoculum per site delivered intradermally/subcutaneously. The titre of the LSDV inoculum was $10^{5.5} \mathrm{TCID}_{50} / \mathrm{ml}$. All animals were housed in biosecure isolation facilities. Animal attendants wore rubber protective clothing, which was washed with an iodophor disinfectant (FAM, Evans) before moving between animal boxes, and before leaving the isolation unit.

One-week-old adult female Ae. aegypti mosquitoes, in cardboard cages with fine mesh screen tops, were fed to engorgement through the netting on LSD lesions of the infected steers 3 days after the appearance of the lesions. Approximately $50 \mathrm{Ae}$. aegypti females were allowed to feed on a lesion. The blood-fed females were then selected in the laboratory, and placed in separate cages and any non blood-fed females were discarded. The mosquitoes were maintained at $25{ }^{\circ} \mathrm{C}, 60 \%$ humidity and were fed on a $10 \%$ sucrose solution, given daily, which was placed on a cotton pad on the terylene netting tops of their cages. To encourage oviposition, filter paper was placed on top of moistened cotton wool in a tubular support at the base of the cages.

Transmission of virus was then attempted by allowing the potentially infected mosquitoes to feed on six susceptible cattle at various times post-infective feeding. Transmission was confirmed by recording clinical signs of LSD or recovering live virus from lesion material or the blood of susceptible animals.

\section{DNA extraction from mosquitoes}

After an infected blood meal, 10 engorged mosquitoes were removed from the holding cages. Of these, 5 mosquitoes were subjected to the DNA extraction protocol of Cheung et al. [17]. The DNA extracted was assayed by the polymerase chain reaction (PCR) method described by Ireland and Biinepal (1999) [18]. Five mosquitoes that had previously engorged were removed from the holding cages on each of days 2, 3, 
Table 1. The clinical response of animals exposed to LSDV infected mosquitoes measured using the following scale

\begin{tabular}{lllll}
\hline \hline $\begin{array}{l}\text { Reaction } \\
\text { score }\end{array}$ & Generalization & $\begin{array}{l}\text { Lymph node } \\
\text { enlargement }\end{array}$ & Local lesion & Other comments \\
\hline Mild & - & + & Transient & $\begin{array}{l}\text { Transient reaction at inoculation site } \\
\text { Mild regional lymphadenopathy }\end{array}$ \\
& & & $\begin{array}{l}\text { No systemic disturbance } \\
2-3 \text { secondary lesions }\end{array}$ \\
& & & $\begin{array}{l}\text { Heat and pain at inoculation site } \\
\text { Pyrexia and depression } \\
\text { Conjunctivitis and rhinitis }\end{array}$ \\
& $+1-$ & $<6 \mathrm{~cm}$ diam & $\begin{array}{l}\text { Severe general lymphadenopathy Anorexia } \\
\text { Severe general lymphadenopathy } \\
\text { Severe conjunctivitis/rhinitis }\end{array}$ \\
& & & $\begin{array}{l}\text { Numerous secondary papules } \\
\text { Humane destruction necessary }\end{array}$ \\
\hline \hline
\end{tabular}

4, 5 and 6 post-feeding on an infected animal. DNA was similarly extracted from these mosquitoes, and assayed by PCR.

\section{Experimental design}

Non-heparinized blood was collected for serology from a healthy Holstein-Friesian and five Angus cross Jersey steers. The animals were then exposed to potentially infected mosquitoes at intervals of $48 \mathrm{~h}, 3$, 4,5 and 6 days post-infective feeding. Nonheparinized blood from each susceptible steer was collected for serology immediately before mosquito feeding took place. The susceptible animals had four shaved feeding sites on their necks and flanks. A total of approximately 200 mosquitoes were allowed to feed to engorgement on the four shaven sites on the neck and flank of each animal. Feeding was deemed to be complete when probing activity ceased. The susceptible animals were then monitored for clinical signs of LSD. Blood samples for serology and virus isolation were collected daily. The animals were scored on the severity of the clinical reaction to infection with the mosquito-transmitted virus (Table 1). Five mosquitoes from each batch were assayed for LSDV by PCR and virus isolation immediately post re-feeding.

\section{RESULTS}

Table 1 shows the criteria used to determine the severity of disease in infected animals. The clinical response to LSD, of cattle exposed to the bites of infected mosquitoes is summarized in Table 2. Five out of six susceptible animals developed clinical LSD after infected mosquitoes were allowed to feed on them. Four out of five susceptible animals (TW6-9) developed mild clinical LSD, mainly localized swelling at feeding sites with regional lymphadenopathy. Steer TW10 did not develop clinical LSD. However, steer TU39 showed a more severe response with the development of conjunctivitis, rhinitis and pyrexia lasting 3 days. Also, a swelling was observed on one feeding site $24 \mathrm{~h}$ later and this developed into a nodule about $3 \mathrm{~cm}$ in diameter. Primary lesions were seen on two other feeding sites. At 15 days post-feeding, three secondary lesions were observed around the first feeding site. The primary lesion developed into an ulcer, which subsequently formed a scab. Using the reaction score system outlined in Table 1, steer TU39 developed moderate LSD. Table 2 summarizes the results of virus isolation from the buffy coat of the animals in the study. Virus isolation and PCR both detected capripoxvirus confirming transmission of LSDV from $48 \mathrm{~h}$ up to 6 days post-feeding by infected mosquitoes. One animal (TW10) did not develop LSD lesions but virus was detected in the buffy coat showing that transmission of LSDV had occurred. The virus neutralization index showed 3 animals with a neutralization index of greater than $\log _{10} 1 \cdot 5$, which is considered indicative of exposure and response to LSDV. Table 3 shows the results of PCR and virus isolation from samples of mosquitoes immediately after the infective feed and just before re-feeding on susceptible animals. It is evident that many mosquitoes were able to retain virus for a period up to 6 days post feeding on an infected animal. Table 3 also shows that mosquitoes acquired a mean infection of $10^{3 \cdot 3} \mathrm{TCID}_{50}$ of virus/mosquito on day 0 immediately 
Table 2. Summary of the responses of animals in experiments 1 and 2 following exposure to LSDV infected mosquitoes

\begin{tabular}{llllll}
\hline \hline Steer ID & PCR* & Virus isolation & Clinical score & VNI $\dagger$ & $\begin{array}{l}\text { Duration over which } \\
\text { transmission was recorded }\end{array}$ \\
\hline TU39 & $+($ day 6) & + & Moderate & $1 \cdot 7$ & $48 \mathrm{~h}$ \\
TW6 & $+($ day 8$)$ & + & Mild & $1 \cdot 5$ & $48 \mathrm{~h}$ \\
TW7 & + (day 7) & + & Mild & $1 \cdot 5$ & 3 days \\
TW8 & $+($ day 9) & + & Mild & $1 \cdot 4$ & 4 days \\
TW9 & $+($ day 10) & + & Mild & $1 \cdot 0$ & 5 days \\
TW10 & $+($ day 10) & + & No reaction & $0 \cdot 5$ & 6 days \\
\hline \hline
\end{tabular}

* Figures in parentheses refer to days post feeding that viral DNA was detected by PCR.

$\dagger$ VNI, virus neutralization index.

Table 3. Results of polymerase chain reaction and virus isolation on mosquitoes fed on an LSDV infected steer*

\begin{tabular}{|c|c|c|c|c|}
\hline \multirow[b]{3}{*}{ Day } & \multirow{3}{*}{$\begin{array}{l}\text { Transmission of LSDV } \\
\text { to susceptible animal }\end{array}$} & \multicolumn{3}{|l|}{ Aedes aegypti } \\
\hline & & \multirow{2}{*}{$\begin{array}{l}\text { PCR } \\
\text { No infected/ } \\
\text { no tested }\end{array}$} & \multicolumn{2}{|c|}{$\begin{array}{l}\text { Virus isolation } \\
\text { Virus titre per mosquito } \\
\left(\log _{10}\right)\end{array}$} \\
\hline & & & Range & Mean \\
\hline $0 \dagger$ & Not tested & $5 / 5$ & $2 \cdot 6-4 \cdot 0$ & $3 \cdot 3$ \\
\hline 2 & Yes & $3 / 5$ & $2 \cdot 9-3 \cdot 9$ & $3 \cdot 3$ \\
\hline 3 & Yes & $4 / 5$ & $2 \cdot 0-2 \cdot 6$ & $2 \cdot 4$ \\
\hline 4 & Yes & $4 / 5$ & $2 \cdot 0-2 \cdot 7$ & $2 \cdot 4$ \\
\hline 5 & Yes & $2 / 5$ & $2 \cdot 3-2 \cdot 5$ & $2 \cdot 4$ \\
\hline 6 & Yes & $3 / 5$ & $2 \cdot 5-2 \cdot 8$ & $2 \cdot 5$ \\
\hline
\end{tabular}

* Virus content of primary lesion: $10^{6 \cdot 3} \mathrm{TCID}_{50} / \mathrm{gm}$ tissue.

$\dagger$ Mosquitoes tested immediately after their infective feed on day 0 .

after feeding on an infected animal. By day 6, mosquitoes retained an average of $10^{2 \cdot 5} \mathrm{TCID}_{50} /$ mosquito. All the groups of mosquitoes sampled from $48 \mathrm{~h}$ to 6 days post re-feeding on infected steers were able to transmit LSDV to susceptible cattle.

\section{DISCUSSION}

Biting insects have long been implicated in the transmission of LSDV on epidemiological grounds, and several studies have confirmed that the transmission of the virus in an arthropod-free environment does not occur [19,20; Alexander, personal communication]. In this context, mosquito species are ideal vector candidates since they tend to be intravenous feeders, and previous studies have demonstrated that the intravenous inoculation of LSDV into cattle predisposes to generalization and severe disease [20]. However, until now no data has been published that proves, definitely, that any species of arthropod can transmit LSDV from infected to susceptible vertebrate hosts.

The results of the present investigation show that LSDV can be transmitted by Ae. aegypti from infected to susceptible cattle, for at least 6 days after the mosquitoes' infection. Since other work (Chihota, unpublished observations) indicates no evidence of virus replication in the insect vector, the mode of transmission must be mechanical. These findings provide a significant addition to our understanding of the epidemiology of LSD, as this is the first time that transmission of LSDV, by an insect vector, has been confirmed. Although virus has been isolated from biting insects before, attempts at transmission to susceptible animals have been unsuccessful [19]. Previously, speculation on the transmission of LSDV by biting insects had envisaged the mechanism as being merely a short-term 'dirty needle' type of transference, but the results presented in this study suggest otherwise. Virus is able to survive in infected 
mosquitoes for periods of at least 6 days without an appreciable loss in titre and is then able to be transmitted. This implies that virus could be localized at a site within the mosquito vector where it is protected from inactivation and suggests a far more complex mode of transmission than a mere 'dirty pin'. Indeed, earlier work has shown that Ae. aegypti can harbour infectious LSDV for periods up to 9 days post-infection (Chihota, unpublished observations). These aspects of the relationship between LSDV and its insect vector(s) clearly require further investigation.

This study strongly suggests that Ae. aegypti and possibly other biting insects are likely to be involved in the inter-herd spread of LSDV. The study has also shown that it is possible to transmit LSDV by $A e$. aegypti to susceptible animals without the subsequent development of clinical disease in those animals and this may represent an important aspect of the epidemiology of LSD. Diagnosis of LSD in the field is usually based on observing clinical signs of disease in cattle, but sub-clinically infected animals may also provide additional, "covert" foci of infection for mosquitoes or other biting insects.

To date, Ae. aegypti has been shown only to transmit LSDV under experimental conditions. Whether it is also involved in the transmission of this virus in the field remains to be investigated, but should this prove to be the case, the risk of LSD spreading to areas beyond Africa, where Ae. aegypti also occurs, may need to be reassessed. In the light of the present work, it would be essential to consider the control of biting flies in the face of LSD outbreaks.

\section{ACKNOWLEDGEMENTS}

C.M. Chihota was supported by a grant from the UK Department for International Development. Dr James House (formerly of the United States Department of Agriculture) kindly supplied the Ismailiya strain of LSD virus.

\section{REFERENCES}

1. Prozesky L, Barnard BJH. A study of the pathology of lumpy skin disease in cattle. Onderstepoort J Vet Res 1982; 49: 167-75.

2. Kitching RP, Taylor WP. Transmission of capripoxviruses. Res Vet Sci 1985; 39: 196-9.
3 Davies FG. Lumpy skin disease of cattle: a growing problem in Africa and the Near East. World An Rev 1991; 37-42.

4. Yeruham I, Braverman Y, Davidson M. Retrospective study on the epidemiology of the first lumpy skin disease outbreak in Israel in 1989. IXth International Congress of Virology, Glasgow, Scotland, 8-13 August 1993.

5. Yeruham I, Nir O, Braverman Y, Davidson M, Grinstein H, Haymovitch M, Zamir O. Spread of lumpy skin disease in Israeli dairy herds. Vet Rec 1995; 137: 91-3.

6. Diesel AM. The epizootiology of lumpy skin disease in South Africa. Rep Int Vet Congress, London 1949; 492-500.

7. Burdin ML, Prydie J. Observations on the first outbreak of lumpy skin disease in Kenya. Bull Epizoot Dis Africa, 1959; $7: 21-6$.

8. Kitching RP, Mellor PS. Insect transmission of capripoxviruses. Res Vet Sci 1986; 40: 255-8.

9. Mellor PS, Kitching RP, Wilkinson PJ. Mechanical transmission of capripoxvirus and African swine fever virus by Stomoxys calcitrans. Res Vet Sci 1987; 43: 109-12.

10. Webb G. Studies on the mechanical transmission of animal viruses by biting flies. PhD thesis, Council of National Academic Awards, UK, 1990.

11. Fenner F, Day MF, Woodroofe GM. The mechanism of the transmission of myxomatosis in the European rabbit (Oryctolagus cuniculus) by the mosquito Aedes aegypti. Aust J Exp Biol Med Sci 1952; 30: 139-52.

12. Kilham L, Dalmat HT. Host-virus mosquito relations to Shope fibromas in cotton tail rabbits. Am J Hyg 1955; 61: 45-54.

13. Brody AL. The transmission of fowl pox. Cornell University Agric Experimental Station Mem, 1936: 165.

14. Ferris RD, Plowright W. Simplified methods for the production of monolayers of testis cells from domestic animals, and for the serial examination of monolayer cultures. J Pathol Bacteriol 1958; 75: 313-8.

15. Karber G. Beitrag zur kollektiven Behandlung pharmakologischer Reihenversuche. Arch Exp Path Pharmak 1931; 162: 480-3.

16. Kitching RP. OIE manual of standards for diagnostic tests and vaccines, 3rd edn. 1996; 96-7.

17. Cheung WY, Hubert N, Landry BS. A simple and rapid DNA microextraction method for plant, animal and insect suitable for RAPD and other PCR analysis. PCR Methods and Applications, 1993; 3 (No. 1): 69-70.

18. Ireland DC, Binepal YS. Improved detection of capripoxvirus in biopsy samples by PCR. J Virol Meth 1998; 74: 1-7.

19. Weiss KE. Lumpy skin disease virus. Mon Virol 1968; 3: 111-31.

20. Carn VM, Kitching RP. An investigation of possible routes of transmission of lumpy skin disease virus (Neethling). Epidemiol Infect 1995; 114: 219-26. 